\title{
Factors Militating Against Prompt Delivery of Construction Projects in Lagos Megacity, Nigeria: Contractors' Perspective
}

Ogunde, Ayodeji Olubunmi ${ }^{1 *}$

Dafe, Odje Emmanuel ${ }^{1}$

Akinola, Gbemisola Ajoke ${ }^{1}$

Ogundipe, Kunle Elizah ${ }^{1}$

Oloke, Olayinka Clement²

Ademola, Sakariyau Adeboye ${ }^{1}$

Akuete, Eseohe ${ }^{1}$

\section{Olaniran, Hezekiah Farayola1}

${ }^{1}$ Department of Building Technology, Covenant University, Ogun State, Nigeria ${ }^{2}$ Department of Estate Management, Covenant University, Ogun State, Nigeria

${ }^{*}$ Corresponding Author

Doi:10.5901/mjss.2017.v8n3p233

\begin{abstract}
Delay is a common issue faced in the construction industry all over the world especially in developing countries. The aim of this study is to evaluate factors causing delays and their effects on construction projects in Lagos Mega City, Nigeria from the contractors' perspective. It is predicated on the incessant delay experienced by contractors on construction projects. Purposive sampling method was adopted for the study;: Quantitative data was obtained by administration of One hundred (100) structured questionnaires distributed to contractors of construction project sites in Lagos State and Qualitative data was obtained from interview of key management personnel of the companies and journals. Ranking analysis of the 33 major causes of delays identified through literature review using Relative Importance Index (RII) showed that cash flow problems during construction $(R I l=4.81)$, clients' financial difficulties $(R I=4.47)$ and poor procurement $(R I l=4.40)$ were the most importantt causes of delays in construction project sites in Lagos State, Cost overrun $(R I=4.92)$, late payment $(R \|=4.59)$ and project extension $(R / l=4.45)$ were predominant effects of delay in construction project. Hypotheses testing on relationship between shortage of skilled labour, improper equipment during construction and delay in construction project using One-Way ANOVA showed positive correlation. For improved efficiency and effective project delivery in the industry, proper payment from client (RII=4.78), competent project managers $(R I=4.64)$, the use of experienced subcontractors and suppliers $(R I=4.48)$ should be encouraged to mitigate against delay in construction projects.
\end{abstract}

Keywords: Contractors, construction, delay, Nigeria, project

\section{Introduction}

The construction industry is an essential component for driving the economy of any nation hence worldwide, huge amounts of resources are devoted to construction development work. (Aftab Hameed Memon (2014), Davision and Mullen (2009)). Delay is a global phenomenon (Sambasivan and Soon, 2007) which affects not only the construction industry but the overall economy of countries (Faradi and El-Sayegh, 2006). In Nigeria, according to Olusegun Aganga, former Minister of Finance, the construction industry contributes 3\% to national GDP. Delay in construction has adverse effects on all stakeholders in the business. It is therefore in the interest of all to avoid delay, or at best, reduce such 
delays to the minimum, should such arise. Aibinu and Jagboro (2002 defined delay as the extension of time beyond planned completion dates traceable to the contractors. Every delay that the project contractor experience is a setback. Improper planning at the conception of a construction project can be a source of delay which may lead to loss of productivity. (Ogunde and Fagbenle 2013).

Bureaucratic bottlenecks arising as a result of processes, procedures and government policies relating to approvals are critical to timely delivery of construction projects. Government officials storming of construction site to stop work due to non-payment of certain fees is a common sight in the industry. In every construction site, the contractor is faced with onerous tasks of managing scarce financial resources which may be to inadequate working capital. The contractor constantly faces the task of proper management of materials. The contractor also is constantly faced with the problem of equipment management and government officials incessant harassment leading to 'stop work' orders is a major cause for concern to the contractors. These factors make the execution of construction projects by the contractor very hazardous, unpredictable, uncertain and therefore susceptible to delays as a result of non-compliance with certain policies, procedures and practices.

The aim of this study is to carry out evaluation of causes of delay in construction project from the contractors' perspective. The study is predicated on the incessant delay experienced in construction projects by contractors. The objectives are:

- To assess the causes of delay rated by contractors.

- To determine the effects of delay in construction projects.

- To identify methods to mitigate delay based on findings of study.

The research tested the following hypotheses:

$\mathrm{H}_{0}$ : Shortage of skilled labour will not lead to delay in construction project.

$\mathrm{H}_{0}$ : Improper equipment during construction cannot lead to project delay.

The study was carried out on construction project sites in Lagos Island, Lagos State. It focused on the evaluation of delay in construction projects from the contractors' perspective. Lagos is the economic capital of Nigeria. As it aspires to become a megacity, and with the recent coming on stream of Eko Atlantic Authority. It aims to reclaim parts of Bar Beach and transform it into sprawling private residential and commercial estates, the complexion of the construction industry in the Victoria Island area of the city is bound to take a new dimension. Moreover, the influx of the affluent towards Lagos Island compels an investigation of this magnitude in order to ascertain delay factors in the construction industry, as related to the contractor and proffer solutions to ameliorate same.

\section{Literature Review}

Acharya et al. (2006), emphasised that major causes of delays in construction are the client, the contractor, the consultants, acts of God, or a third party. Aibinu and Jagboro (2002) stated that delay may occur when the contractor and the project owner jointly or severally contributed to the non-completion of the project within the original or the stipulated or agreed contractor period. Fugar and Agyakwah-Baah (2010), contended that contractual disagreement may cause delay and cost overrun. This involves multiple complex issues that concern entitlement to recover costs of delay and adjustments of the contract schedules.

Owolabi et al (2014), stated that delay ranks very high in project execution in Nigeria while Sanni and Hashim (2013) discovered that the major problems plaguing the construction in Nigeria are improper documentation, inexperienced staff, unstable market conditions, project complexity, unstable government regulations, wrong procurement methods and lack of innovation. Odeyinka and Yusuf (1977) concluded that seventy percent of projects surveyed in Nigeria suffered failure due to delay in their execution. Moreover, delay is costly, complex and risky (Alaghbari et al (2005).

\subsection{Related studies on Causes of Delay}

Frimpong and Oluwoye (2003) grouped causes of delay into four categories namely project financing, economic and natural conditions and material supplies. While, Ahmed et al (2003) grouped delays into two main categories: Internal delays caused by the parties to the contract such as the client, designer, consultants and the contractor. External delays caused not by the parties to the contract.. These include government action, material suppliers and act of God, etc. However Ayman (2000) concluded that the main causes of delay in construction of public projects relate to designers, users changes, weather, site conditions, late delivery of materials, economic condition and increase in quantity. Similarly, Sweis et al (2008) concluded that financial difficulties faced by the contractor and too many change orders by owners are 
the major causes of construction delay. Odeh and Battaneth (2001) claimed that delays were caused by owner interference, inadequate contractor experience, financing and payments, labour productivity, slow decision making, improper planning and sub-contractors.

Abd El-Razek et al (2008) discovered that the most important causes of delay are financing by contractor during construction, delays in payment to contractors by client, design changes by client or his agent during construction, partial payment during construction and non-utilization of professional construction/contractual management.

Assaf and Al and Al-Hejji (2006) conducted a time performance survey of different types of construction projects in Saudi Arabia and concluded delay is the highest factor.. Muhwezi et al (2014) considered the following four factors: consultant-related, client related, contractor-related and external-related. Improper planning and lack of communication were reported as main causes of delay and time overrun in the construction industry in Nigeria, Isah, K.M.M.A.D. (2012).

\subsection{Related Studies on Classification of Delay}

Bolton (1990) classified delay into three broad categories namely Excusable but non-compensable delay: Compensable delays; Inexcusable delays Inexcusable delays (non-excusable delays) are caused solely by the contractor or its suppliers (Fugar and Agyakwah-Baah, 2010).

(Soon, 2010) (Majid, 2006) and (Luu et al., 2009). Another classification of delay according to (Ahmed et al., 2003) is concurrent delays;

There are several studies on causes of delays as tabulated as follows:

Table: Summary of other Causes of Delay

\begin{tabular}{|c|c|c|}
\hline $\mathrm{S} / \mathrm{N}$ & Factors & Authors \\
\hline 1 & $\begin{array}{l}\text { Contractor's financial difficulties } \\
\text { - delay in payment from client would cause financial difficulties to the } \\
\text { contractor. } \\
\text {-Inadequate fund allocation, High interest rates } \\
\text { - insufficient profit and insufficient capital } \\
\text {-poor financial control by the contractor }\end{array}$ & $\begin{array}{l}\text { Arshi and Sameh (2005), Arditi et al (1985), Al-Khalil and } \\
\text { Al-Ghafly (1999), Frimpong et al (2003), } \\
\text { Assaf and Al-Hejij (2006), Sambasivan and Yau (2007) } \\
\text { Coulter and Kelley (1992) Thorton (2007 } \\
\text { Liu (2010) }\end{array}$ \\
\hline 2 & $\begin{array}{l}\text { Material supplies difficulties } \\
\text { - Unreliable suppliers can also be a factor in material shortages } \\
\text { - suppliers' failure to deliver on time can lead to disruption in } \\
\text { operations and cause delay. }\end{array}$ & $\begin{array}{l}\text { Dada et al (2007) } \\
\text { Ruiz-Torres and Farzad (2006), } \\
\text { Van der Rhee et al (2009) Aibinu and Odeyinka (2006) }\end{array}$ \\
\hline 3 & $\begin{array}{l}\text { Labour difficulties } \\
\text { - shortage of manpower including skilled, semi-skilled and unskilled } \\
\text { labour causes delay in construction projects. }\end{array}$ & $\begin{array}{l}\text { Wang (2010), Sweis et al (2008) and Sambasivan and } \\
\text { Yau (2007) }\end{array}$ \\
\hline 4 & $\begin{array}{l}\text { Equipment and tools shortages } \\
\text { - Insufficient amount of equipment, Frequent equipment breakdown, } \\
\text { Shortage of equipment parts, Improper equipment }\end{array}$ & Chang et al (1991) \\
\hline 5 & $\begin{array}{l}\text { Poor site management difficulties } \\
\text { - Poor site management will affect the overall team resulting in } \\
\text { eventual outcome of project delay. }\end{array}$ & $\begin{array}{l}\text { Studies conducted by Arshi and Sameh (2006), Arditi et } \\
\text { al (2005) and Faridi and El-Sayegh (2006) }\end{array}$ \\
\hline 6 & $\begin{array}{l}\text { Coordination difficulties } \\
\text { - difficulties in coordination between the separate parties are one of } \\
\text { the factors that contribute to delay } \\
\text { - difficulty and frequent communication breakdown. }\end{array}$ & $\begin{array}{l}\text { Assaf et al (1995), Majid and McCaffer (1998), } \\
\text { Sambasivan and Yau (2007), }\end{array}$ \\
\hline 7 & $\begin{array}{l}\text { Construction Errors and defective works } \\
\text {-poor workmanship, carelessness and short-cuts are the three main } \\
\text { factors that contribute to defective works. construction mistakes. } \\
\text {-contractor usually undertake short-cuts to complete the construction } \\
\text { work due to time and cost constrains. }\end{array}$ & $\begin{array}{l}\text { Gerskup (2010, } \\
\text { Thomas (1991) }\end{array}$ \\
\hline
\end{tabular}

\subsection{Previous Studies on effects of delay.}

Studies from Aibinu and Jagboro (2002), Sambasivan and Yau (2007) and Sun and Meng (2009) indicated effects of delay in construction projects include Cost overrun. Other studies are Singh (2009); Aibinu and Jagboro (2002), 
Sambasivan and Yau (2007 Hanna et al (2004), Sun and Meng (2009)). On extension of time are these studies Odeh and Battaineh (2002), (Othman et al (2006) and William (2003); On late payment are these Still (2002; Odeh and Battaineh (2001); Rescheduling (Vieira (2003), and Liu and Shih (2009); On damage Company's reputation are Djordjevic and Djukic (2008). Ismail et al (2006) Ismail et al (2006); On productivity and efficiency are (McDonald and Zack (2004); Bramble and Callahan (2002)..

\section{Research Methods}

The study was conducted in Lagos Island. The sample of this study was derived from workers of notable construction firms with sites in Lagos Island. The respondents were deliberately selected on account of their well-organized structures at both offices and construction sites in terms of nature and volume of business activities. This includes but not limited to numbers of employees, expatriates, skilled and unskilled, deployment of heavy construction equipment, material procurement and deployment logistics, clients' profile, general work environment and adherent to best practices. The construction works investigated for this study included residential and office building projects in Lagos Island. The study considered some of the directorate, management, senior and supervisory staff of these construction firms who are involved in the day-to-day decision making process at different levels, for the sample frame

\subsection{Data Collection}

The data used for this research comprises both Primary and Secondary data. The instrument of data collection employed is the questionnaire. The collection instruments were targeted at obtaining useful information on delay in construction projects from the contractors' perspective. The questions were drawn based on the research questions, aim and objectives, literature review and research hypothesis that were tested. Relative Importance Index method was used to determine the relative importance of the various causes and effects of delays. The five-point likert scale ranged from 1 (strongly disagree) to 5 (strongly agree) was adopted and transformed to relative importance indices (RII) for each factor as follows:

$\mathrm{RII}=\sum \mathrm{W} / \mathrm{SA} * \mathrm{~N}$

Where, $W$ is the weighting given to each factor by the respondents ranging from 1 (strongly disagree) to 5 (strongly agree), $\mathrm{SA}$ is the highest weight (i.e. 5 in this case), and $\mathrm{N}$ is the total number of respondents. The RII value had a range from 1 to 5 , higher the value of RIl, the more important the cause of delays.

\section{Data Analysis}

Hypothesis one and hypothesis two were analyzed using One-Way ANOVA, to compare means of three or more samples. This technique can be used only for numerical data. (Howell 2002) The calculation of the correlation coefficient was performed by statistical programs SPSS. A total of one hundred (100) questionnaires were distributed in different construction sites, and Eighty-Six (86) questionnaires (representing 86\%) were returned, while fourteen (4) questionnaires (representing 14\%) were not returned.

Table 1: Profession of the respondent

\begin{tabular}{ccccc}
\multicolumn{2}{l}{ Professional Qualification } & \multicolumn{3}{l}{} \\
\hline \hline & Frequency & Percent & Valid Percent & Cumulative Percent \\
\hline \hline ARCH. & 40 & 46.5 & 46.5 & 46.5 \\
Eng. & 18 & 20.9 & 20.9 & 67.4 \\
BLDR & 15 & 17.4 & 17.4 & 84.9 \\
Q.S & 13 & 15.1 & 15.1 & 100.0 \\
Total & 86 & 100.0 & 100.0 & \\
\hline \hline
\end{tabular}

Table1 indicates that $40(46.5 \%)$ of respondents are Architects by profession, 18 (20.9\%) of the respondent are Engineers, $15(17.4 \%)$ of the respondent are Builders and $13(15.1 \%)$ of the respondent are Quantity Surveyors. Architects had the highest percentage in the response of the respondent and this can be attributed to the high percentage of Architects in contracting firms visited. 
Table 2: Academic qualification of the respondents

\begin{tabular}{ccccc} 
Qualification & \multicolumn{3}{c}{} \\
\hline \hline & Frequency & Percent & Valid Percent & Cumulative Percent \\
\hline \hline B.Sc/BEng & 54 & 62.8 & 62.8 & 62.8 \\
HND & 21 & 24.4 & 24.4 & 87.2 \\
M.Sc & 11 & 12.8 & 12.8 & 100.0 \\
Total & 86 & 100.0 & 100.0 & \\
\hline \hline
\end{tabular}

Table 2 shows that 54 (62.8\%) of the respondents had B.sc/BEng , while $21(24.4 \%)$ of the respondents had HND and 11 $(12.8 \%)$ of the respondents had Master's Degree level. B.Sc/BEng has the highest percentage in the response of the respondents.

Table 3: Years of experience of the respondent

\begin{tabular}{ccccc}
\multicolumn{2}{l}{ Years of Experience } \\
\hline \hline & Frequency & Percent & Valid Percent & Cumulative Percent \\
\hline \hline $0-5 y r s$ & 3 & 3.5 & 3.5 & 3.5 \\
$6-10 y r s$ & 10 & 11.6 & 11.6 & 15.1 \\
$11-15 y r s$ & 31 & 36.1 & 36.1 & 51.2 \\
$>16 y r s$ & 42 & 48.8 & 48.8 & 100.0 \\
\hline Total & 86 & 100.0 & 100.0 & \\
\hline \hline
\end{tabular}

Table 3 shows that 3 (3.5\%) of the respondent had 1-5 years of working experience, 10 (11.6\%) had 6-10 years working experience, $31(36.1 \%)$ had $11-15$ years of working experience and $42(48.8 \%$.) had $>16$ years of working experience.. $>16$ years of working experience had the highest percentage of working.

Table 4: Causes of delay faced by contractors

Causes of Delay Faced by Contractors

\begin{tabular}{lcc}
\hline \hline & Mean & Ranking index \\
\hline \hline Cash flow Problems During Construction & 4.8140 & 1 \\
Clients Financial Difficulties & 4.4651 & 2 \\
Poor Procurement & 4.3953 & 3 \\
Inadequate Fund Allocation & 4.3837 & 4 \\
\hline Shortage of Skilled Labour & 4.0581 & 5 \\
Abnormal Increase in Material Prices & 3.9884 & 6 \\
Labour Productivity & 3.9767 & 7 \\
Delayed Delivery of Materials & 3.9419 & 8 \\
Construction Methods & 3.8837 & 9 \\
Insufficient Equipment & 3.8256 & 10 \\
Poor Quality & 3.8023 & 11 \\
Inadequate Construction Materials & 3.7442 & 12 \\
Unclear \& Inadequate Details In Drawings & 3.7326 & 13 \\
Unreliable Suppliers & 3.6977 & 14 \\
Improper Equipment & 3.6744 & 15 \\
Poor Site Management \& Supervision & 3.6512 & 16 \\
Slow Mobilisation & 3.6279 & 17 \\
Labour Supply & 3.5930 & 18 \\
Slow Mobilization of Labour & 3.5698 & 19 \\
Lack of Modern Equipment & 3.4884 & 20 \\
Lack of Construction Production Plan & 3.4767 & 21 \\
Inadequate Time of Completion & 3.3837 & 22 \\
Difficulty In Acquiring Loan & 3.3372 & 23 \\
Frequent Equipment Breakdown & 3.3023 & 24 \\
Inadequate Data Collection \& Survey Before Design & 3.2558 & 25 \\
& & \\
\hline
\end{tabular}




\begin{tabular}{|c|c|c|}
\hline Late Production of Design Documents & 3.2209 & 26 \\
\hline Underestimation of Complexity of Projects & 3.1047 & 27 \\
\hline Equipment Allocation Problems & 3.0465 & 28 \\
\hline Under Estimation of Costs of Projects & 3.0233 & 29 \\
\hline Low Motivation \& Morale & 2.4884 & 30 \\
\hline Strike & 2.2326 & 31 \\
\hline Absenteeism & 2.0814 & 32 \\
\hline
\end{tabular}

Table 4 shows that cash problems during construction (4.8140), client financial difficulties (4.4651) and poor procurement (4.3953), inadequate fund allocation (4.3837) and shortage of skilled labour (4.0581) are ranked the major causes of delay in construction sites in Lagos Island.

Table 5: Effects of delay in construction projects from contractors' perspective

\begin{tabular}{lcc} 
Effects of Delay Faced by Ontractors & & \\
\hline \hline & Mean & Ranking Index \\
\hline \hline Cost Overrun & 4.9186 & 1 \\
Late Payment & 4.5930 & 2 \\
Project Extension & 4.5814 & 3 \\
Rescheduling & 4.4535 & 4 \\
Disputes & 3.8372 & 5 \\
Arbitration & 3.7093 & 6 \\
Litigation & 3.6047 & 7 \\
Poor Quality of End Product & 3.5698 & 8 \\
Damage Company Reputation & 3.1512 & 9 \\
Loss Of Productivity \& Efficiency & 3.1395 & 10 \\
Total Abandonment & 2.3837 & 11 \\
\hline \hline
\end{tabular}

Table5 shows cost overrun (4.9186), late payment (4.5930) and Project Extension (4.5814) which were ranked1 ${ }^{\text {st }}, 2^{\text {nd }}$ and $3^{\text {rd }}$ respectively followed by rescheduling (4.4535), disputes (3.8372), and arbitration (3.7093) which were ranked $4^{\text {th }}, 5^{\text {th }}$ and $6^{\text {th }}$ respectively. These are the six major effects of delay faced by contractors in construction in Lagos Island.

Table 6: Methods to minimize delays in construction

Methods to Minimize Delay in Construction

\begin{tabular}{lcc}
\hline \hline & Mean & Ranking Index \\
\hline \hline Proper Payment From Client & 4.7791 & 1 \\
Use of Proficient Project Manager & 4.6395 & 2 \\
Use of Experienced Subcontractors \& Suppliers & 4.4767 & 3 \\
Experienced Project Team & 4.4767 & 4 \\
Use of Appropriate Construction Methods & 4.3837 & 5 \\
Frequent Progress Meetings & 4.3488 & 6 \\
Proper Planning & 4.3140 & 7 \\
Good Schedulling \& Programme & 4.1977 & 8 \\
Preconstruction Planning of Project Task & 4.1744 & 9 \\
Making Risk Management & 3.9419 & 10 \\
Acceleration of Site Clearance & 3.3488 & 11 \\
Client Representative For Project & 3.3256 & 12 \\
Compute Amouint For Financial Damages & 3.1512 & 13 \\
& & \\
\hline \hline
\end{tabular}

Table 6 shows that proper payment from client (4.7791), competent project manager, (4.6395), use of experienced subcontractors \& suppliers ( 4.4767 ) were ranked $1^{\text {st }}, 2^{\text {nd }}$ and $3^{\text {rd }}$ respectively, multidisciplinary/competent project team (4.4767), use of appropriate construction methods (4.3837), were ranked $4^{\text {th }}$ and $5^{\text {th }}$ respectively.. These are the top five methods in mitigating delay in Lagos Island construction sites. 
Table 7: Ranking of Categories of causes of delay

\begin{tabular}{lcc}
\hline \hline Factors & Mean & Ranking \\
\hline \hline Financial Difficulties & 4.200 & 1 \\
Material Difficulties & 3.971 & 2 \\
Labour Difficulties & 3.799 & 3 \\
Inadequate Equipment & 3.498 & 4 \\
Controlling \& Schedulling & 3.372 & 5 \\
Poor Site Management & 3.561 & 6 \\
& & \\
\hline
\end{tabular}

Table 7 shows the mean and ranking of various causes of delay categorized into groups. Financial difficulties was ranked as $1^{\text {st }}$ cause of delay while material difficulties and labour difficulties were ranked $2^{\text {nd }}$ and $3^{\text {rd }}$. Lack of finance, materials, labour difficulties would lead to major delay on site.

\section{Hypothesis Testing}

\subsection{Hypothesis one}

$\mathrm{H}_{0}$ : Shortage of skilled labour will not lead to delay in construction project.

$\mathrm{H}_{1}$ : Shortage of skilled labour will lead to delay in construction project.

Table 8: Hypothesis One using ANOVA

\begin{tabular}{|c|c|c|c|c|c|c|c|}
\hline & & Sum of Squa & sdfM & an Square & $\mathbf{F}$ & Sig. & Decision \\
\hline \multirow[t]{3}{*}{ Poor Quality of end Product } & Between Groups & 23.594 & 3 & 7.865 & 13.032 & .000 & Accept $\mathrm{Hi}$ \\
\hline & Within Groups & 49.487 & 82 & .604 & & & \\
\hline & Total & 73.081 & 85 & & & & \\
\hline \multirow[t]{3}{*}{ Project Extension } & Between Groups & 13.443 & 3 & 4.481 & 21.012 & .000 & Accept Hi \\
\hline & Within Groups & 17.487 & 82 & .213 & & & \\
\hline & Total & 30.930 & 85 & & & & \\
\hline \multirow[t]{3}{*}{ Total Abandonment } & Between Groups & 5.842 & 3 & 1.947 & 3.758 & .014 & Accept Ho \\
\hline & Within Groups & 42.495 & 82 & .518 & & & \\
\hline & Total & 48.337 & 85 & & & & \\
\hline \multirow[t]{3}{*}{ Disputes } & Between Groups & 11.259 & 3 & 3.753 & 16.670 & .000 & Accept Hi \\
\hline & Within Groups & 18.462 & 82 & .225 & & & \\
\hline & Total & 29.721 & 85 & & & & \\
\hline \multirow[t]{3}{*}{ Cost Overun } & Between Groups & .184 & 3 & .061 & .806 & .494 & Accept Ho \\
\hline & Within Groups & 6.246 & 82 & .076 & & & \\
\hline & Total & 6.430 & 85 & & & & \\
\hline \multirow[t]{3}{*}{ Late Payment } & Between Groups & 4.694 & 3 & 1.565 & 7.104 & .000 & Accept Hi \\
\hline & Within Groups & 18.062 & 82 & .220 & & & \\
\hline & Total & 22.756 & 85 & & & & \\
\hline \multirow[t]{3}{*}{ Reschedulling } & Between Groups & 1.560 & 3 & .520 & 2.159 & .099 & Accept Ho \\
\hline & Within Groups & 19.754 & 82 & .241 & & & \\
\hline & Total & 21.314 & 85 & & & & \\
\hline \multirow[t]{3}{*}{ Damage Company Reputation } & Between Groups & 6.963 & 3 & 2.321 & 6.329 & .001 & Accept Hi \\
\hline & Within Groups & 30.072 & 82 & .367 & & & \\
\hline & Total & 37.035 & 85 & & & & \\
\hline \multirow[t]{3}{*}{ Loss of Productivity \& Efficiency } & Between Groups & 21.454 & 3 & 7.151 & 12.511 & .000 & Accept Hi \\
\hline & Within Groups & 46.872 & 82 & .572 & & & \\
\hline & Total & 68.326 & 85 & & & & \\
\hline \multirow[t]{3}{*}{ Litigation } & Between Groups & 1.943 & 3 & .648 & 1.092 & .357 & Accept Ho \\
\hline & Within Groups & 48.615 & 82 & .593 & & & \\
\hline & Total & 50.558 & 85 & & & & \\
\hline \multirow[t]{3}{*}{ Arbitration } & Between Groups & .779 & 3 & .260 & .453 & .716 & Accept Ho \\
\hline & Within Groups & 46.954 & 82 & .573 & & & \\
\hline & Total & 47.733 & 85 & & & & \\
\hline
\end{tabular}


The decision rule states that if the probability (Asymp. Sig.) is $\leq 0.005$, reject $\mathrm{Ho}$, Accept $\mathrm{Hi}$; and but if the probability (Asymp. Sig.) is $\geq 0.005$, accept $\mathrm{Ho}$, reject $\mathrm{Hi}$.

Table 8, shows that shortage of labour will lead to the following (reject Ho, accept $\mathrm{Hi}$ ):Poor quality of end product .000 , project extension .000 , disputes .000 , late payment .000 , damage of company's reputation .000 , loss of productivity and efficiency .000 because they are less than the probability (Asymp. Sig.). Whereas,, shortage of skilled labour will not lead to the following (accept Ho, reject Hi) :Total abandonment 014, cost overrun .494, litigation .357 \& arbitration .716 because they are greater than the probability (Asymp. Sig.).

\subsection{Hypothesis two}

$\mathrm{H}_{0}$ : improper equipment during construction cannot lead to project delay.

$\mathrm{H}_{2}$ : improper equipment during construction can lead to project delay.

Table 9: Hypothesis Two using ANOVA

ANOVA

\begin{tabular}{|c|c|c|c|c|c|c|c|}
\hline & & Sum of Squares & Df & Mean Square & $F$ & Sig. & Decision \\
\hline \multirow{3}{*}{ Poor quality of end product } & Between Groups & 47.144 & 2 & 23.572 & 75.430 & .000 & Accept $\mathrm{Hi}$ \\
\hline & Within Groups & 25.938 & 83 & .313 & & & \\
\hline & Total & 73.081 & 85 & & & & \\
\hline \multirow[t]{3}{*}{ Project extension } & Between Groups & 1.508 & 2 & .754 & 2.128 & .126 & Accept Ho \\
\hline & Within Groups & 29.422 & 83 & .354 & & & \\
\hline & Total & 30.930 & 85 & & & & \\
\hline \multirow[t]{3}{*}{ Total abandonment } & Between Groups & 3.915 & 2 & 1.958 & 3.658 & .030 & Accept Ho \\
\hline & Within Groups & 44.422 & 83 & .535 & & & \\
\hline & Total & 48.337 & 85 & & & & \\
\hline \multirow[t]{3}{*}{ Disputes } & Between Groups & 5.424 & 2 & 2.712 & 9.264 & .000 & Accept Hi \\
\hline & Within Groups & 24.297 & 83 & .293 & & & \\
\hline & Total & 29.721 & 85 & & & & \\
\hline \multirow[t]{3}{*}{ Cost over un } & Between Groups & 1.055 & 2 & .528 & 8.147 & .001 & Accept Hi \\
\hline & Within Groups & 5.375 & 83 & .065 & & & \\
\hline & Total & 6.430 & 85 & & & & \\
\hline \multirow[t]{3}{*}{ Late payment } & Between Groups & 7.521 & 2 & 3.761 & 20.489 & .000 & Accept Hi \\
\hline & Within Groups & 15.234 & 83 & .184 & & & \\
\hline & Total & 22.756 & 85 & & & & \\
\hline \multirow[t]{3}{*}{ Reschedulling } & Between Groups & 2.126 & 2 & 1.063 & 4.599 & .013 & Accept Ho \\
\hline & Within Groups & 19.188 & 83 & .231 & & & \\
\hline & Total & 21.314 & 85 & & & & \\
\hline \multirow[t]{3}{*}{ Damage company reputation } & Between Groups & 5.097 & 2 & 2.549 & 6.624 & .002 & Accept Hi \\
\hline & Within Groups & 31.938 & 83 & .385 & & & \\
\hline & Total & 37.035 & 85 & & & & \\
\hline \multirow[t]{3}{*}{ Loss of productivity \& efficiency } & Between Groups & 12.888 & 2 & 6.444 & 9.648 & .000 & Accept Hi \\
\hline & Within Groups & 55.438 & 83 & .668 & & & \\
\hline & Total & 68.326 & 85 & & & & \\
\hline \multirow[t]{3}{*}{ Litigation } & Between Groups & 3.121 & 2 & 1.560 & 2.730 & .071 & Accept Ho \\
\hline & Within Groups & 47.438 & 83 & .572 & & & \\
\hline & Total & 50.558 & 85 & & & & \\
\hline \multirow[t]{3}{*}{ Arbitration } & Between Groups & .545 & 2 & .273 & .479 & .621 & Accept Ho \\
\hline & Within Groups & 47.188 & 83 & .569 & & & \\
\hline & Total & 47.733 & 85 & & & & \\
\hline
\end{tabular}

The decision rule states that if the probability (Asymp. Sig.) is $\leq 0.005$, reject $\mathrm{Ho}$, Accept $\mathrm{Hi}$; and but if the probability (Asymp. Sig.) is $\geq 0.005$, accept Ho, reject Hi.

Table 9, shows that improper equipment during construction would lead to the following (reject Ho, accept Hi): Poor quality of end product 000 , , disputes 000 , cost overrun 001 , late payment 000 , damage of company's reputation 
002, loss of productivity and efficiency 000 because they are less than the probability (Asymp. Sig.).

Whereas improper equipment will not lead to the following (accept Ho, reject Hi): project extension.126, litigation $.071 \&$ arbitrati.621 because they are more than the probability (Asymp. Sig.).

\section{Discussion of Findings}

Hypothesis one stated that Shortage of skilled labour will not lead to delay in construction project. Comparison test was used and the result showed that the Asymp. Sig. value of poor quality of end product at .000, project extension at .000, total abandonment at .014 , disputes at .000 , cost overrun at .494 , late payment at 0.00 , rescheduling at 0.99 , damage company's' reputation at .001 , loss of productivity and efficiency at .000 , litigation at .356 and arbitration at .716 . .Therefore, accept that shortage of skilled labour would lead to the following: poor quality of end product, project extension, disputes, late payment, damage of company's reputation and loss of productivity \& efficiency.

Hypothesis two stated that improper equipment during construction project will not lead to delay. Comparison test was used and the result showed that the Asymp Sig. value of poor quality of end product at .000 , project extension at .126 , total abandonment at .030 , disputes at .000 , cost overrun at .001 , late payment at 0.00 , rescheduling at 0.13 , damage company's' reputation at .002 , loss of productivity and efficiency at .000 , litigation at .071 and arbitration at .621 . Therefore, accept the alternative hypothesis which is: improper equipment during construction would lead to the following: poor quality of end product, disputes, late payment, damage of company's reputation and loss of productivity \& efficiency

\section{Conclusion and Recommendation}

\subsection{Conclusion}

Construction delay is a major factor in project delivery. Project delays have been of concern in the construction industry (Ajanlekoko, 1987; Nkado 1995; Odeyinka and Yusuf, 1997; Aibinu and Jagboro, 2002; Ozdemir, 2010, Olajide et al, 2013). However, identifying the causes of delays in the construction projects from contractors' perspective will to a large extent minimize the effects of the delay. The study therefore, aimed at evaluation of delay in construction projects from the contractors' perspective in Lagos Island Construction sites. In conclusion, it identified that Cash problems during construction (4.8140), client financial difficulties (4.4651) and poor procurement (4.3953), inadequate fund allocation (4.3837) and shortage of skilled labour (4.0581) are the major causes of delay in construction sites in Lagos Island. While cost overrun (4.9186), late payment (4.5930), rescheduling (4.4535), disputes (3.8372), and arbitration (3.7093) are the five major effects of delay in construction in Lagos island faced by contractors. Consequently, the methods of minimizing delay on construction projects from the contractors' perspectives, include Proper payment from client (4.7791), use of proficient project manager,(4.6395), use of experienced subcontractors \& suppliers (4.4767) Experienced project team (4.4767), use of appropriate construction methods (4.3837), are the top methods in mitigating delay in Lagos Island construction sites.

\subsection{Recommendations}

Consequently, it is recommended that to minimize delay on construction projects from the contractors' perspectives. The client should have sound financial backing and appropriate cash flow plan for the project. Engage the services of experienced project team and endeavour to pay the contractor promptly at every stage when due after the work has been certified by competent and proficient project manager. The contractor should use the most appropriate construction methods and also make use of experienced subcontractors and suppliers to avoid delay in delivery of materials and equipment towards prompt and efficient delivery of construction projects.

\section{Acknowledgement}

We wish to express our thanks to Covenant University for funding the research and sponsoring the publication of the paper in this journal.

\section{References}

Abd El-Razek M.E., Bassioni H.A. and Mobarak A.M. (2008): Causes of Delays in Building Construction Projects in Egypt, Journal of Construction Engineering and Management, 34 (11) pg. 831-841 
Acharya, N.K., Lee, Y.D., Kim, S.Y. and Lee, J.C. (2006). Analysis of construction delay factor: A Korean perspective. Proceedings: The 7th Asia Pacific Industrial Engineering and Management Systems Conference. Bangkok, Thailand, 17-20 December.

Aftab H. M (2014): Contractor Perspective On Time Overrun Factors In Malaysian Construction Projects, International Journal of Science Environment and Technology, Vol 3, pg. 1184-1192.

Ahmed S.M., Azhar S., Kappagntula P. Gollapudil D. (2003): Delays in Construction, A Brief Study of Florida Construction Industry, Proceedings of the 39th Annual ASC Conference, Clemson University, Clemson, SC . pg. 257-266,

Aibinu A.A. and Jagboro G.O. (2002): The Effects of Construction Delays On Project Delivery in Nigerian Construction Industry, International Journal of Project Management. 20, pg. 593-599

Alaghbari W.A.M., Razali M.A.K., Salim A. and Ernawati (2005): Factors Affecting Construction Speed of Industrialized Building System in Malaysia, Universiti Putra Malaysia: Master's Thesis

Assaf S.A. and Al-Hejji S. (2006): Causes of Delay in Large Construction Projects, International Journal of Project Management. 24 (4), pg. 349-357

Davision R.P. and Mullen J. (2009): Evaluation Contract Claims, (2nd edition), Blackwell Science, Oxford

Djordjevic B. and Djukic S. (2008): The Impact of Downsizing on the Corporate Reputation, Economics and Organization, 5 (1), pg. 51-62.

Faradi A.S. and El-Sayegh S.M. (2006): Significant Factors Causing Delay in the U.A.E. Construction Industry, Construction Management and Economics, 24 (11), pg. 1167-1176.

Fugar F.D.K. and Adwoa B.A. (2010): Delays in building Construction in Ghana, Australasian Journal of Construction Economics and Building, 10 (2) pg. 103-116,

Hamata D., Anil S., Iyer K.C. and Sameer R. (2012): Analysing Factors Affecting Delays in Indian Construction Projects, International Journal of Project Management, 30 (4) pg. 479-489,

Isah J.M.M.A.D. (2012): Causes of Delay in Nigerian Construction Industry, Inter-Disciplinary Journal of Contemporary Research in Business. 4(2), pg. 785-794

Ismail F., Mustapa M. and Mustapa F.D. (2006): Risk Factors of Contractor's Corporate Reputation, Paper Presented at the $5^{\text {th }}$ IEEE International Conference on Cognitive Informatics, Beijing, China. July, pg. 17-19,

Liu S.S. and Shih K.C. (2009): Construction Rescheduling Based on a Manufacturing Rescheduling Framework, Automation in Construction. 18 (6) pg. 715-723

Luu, V., Kim, S., Van Tuan, N. and Ogunlana, S. (2009). Quantifying schedule risk in construction projects using Bayesian belief networks. International Journal of Project Management, 27(1): 39-50.

Majid, I.A. (2006). Causes and effect of delays in Aceh construction industry. MSc diss. Universiti Teknologi Malaysia.

Murray K. (2003): Managing the Single Greatest Risk Facing Business Today, Communication Management. 8, pg. 142,

Odeh A.M. and Battaineth H. (2002): Causes of Construction Delay: Traditional Contracts, International Journal of Project Management, 20(1) pg. 67-73,

Odeyinka H.A., Yusif A. (1997): The Causes and Effects of Construction Delays on Completion Cost of Housing Projects in Nigeria, Journal of Financial Management Property Construction, 2 (3) pg. 31-44,.

Olajide T I, Timo O O, Onaopepo A and Idowu V E (2013), Analysis of Non-Excusable Delay Factors Influencing Contractors' Performance in Lagos State, Nigeria, Journal of Construction in Developing Countries, 18(1), 53-72, 2013

Ogunde A.O and Fagbenle,O.I. (2013). 'Assessment of Effectiveness of Planning Techniques and Tools on Construction Projects in Lagos State.' In Anumba, C and Memari A.M. (Ed.) Building Solution for Architectural Engineering, Architectural Engineering Institute of the American Society of Civil Engineers (AEI), Virgina, USA, pp 396-407

Othman A.A. Torrance, J.V. and Hamid M.A. (2006): Factors Influencing the Construction Time Performance of Public Projects in Malaysia, Engineering Construction and Architectural Management, 13 (5), Pg. 481-510, .

Owolabi james D., Amusan Lekan M., Oloke C.O., Olusanya O., Tunji Olayeni P., Owolabi \ Dele, Peter Joy and Omuh Ignatus (2014):Causes and effects of delays on project construction delivery time International Journal of Education and Research, Vol 2, No.4.

Ozdemir, M. (2010). A probabilistic schedule delay analysis in construction projects by using fuzzy logic incorporated with relative importance index (RII) method. MSc diss. Middle East Technical University.

Rwelamila P.D., AND Hall K.A. (1995): Total System Intervention and Integrated Approach to Time, Cost and Quality management, Construction Management and Economics, pg. 235-241.

Sambasivan M. and Soon Y.W. (2007): Causes and Effects of Delays in Malaysian Construction Industry, International Journal of Project Management, 25 (5), pg. 517-526,

Sanni A. and Hashim. (2013): Assessing the Challenges of Cost Control Practices in Nigeria Construction Industry, Inter-Disciplinary Journal of Contemporary Research Business, 4 (9)

Soon, T.K. (2010). Dispute resolution in relation to delay of construction projects. MSc diss. Universiti Teknologi Malaysia Still K.: Solving the International Problems of Late Payment, Credit Control, 21 (6) pg. 14-20.

Sun M. and Meng X. (2009): Taxanomy for Change Causes and Effects in Construction Projects, International Journal of Project Management. 27, pg. 560-572,

Vieira G.E., Herrmann J.W. and Lin E. (2003): Rescheduling Manufacturing System: A Framework of Strategies, Policies and Methods, Journal of Scheduling. 6, pg. 39-62

Williams T. (2003): Assessing Extension of Time Delays on Major Projects, International Journal of Project Management, 21 (1), pg. 19-26 